\title{
Innovative Susceptibility in the Regional Innovation System
}

\author{
Galina Yakovlevna Belyakova ${ }^{1}$, Olga Nikolaevna Vladimirova ${ }^{1}$, Aida Talyatovna Petrova ${ }^{1} \&$ Alexander \\ Savelevich Shchitnikov ${ }^{1}$ \\ ${ }^{1}$ Siberian Federal University, Krasnoyarsk, Svobodnij Prospect, Russian Federation \\ Correspondence: Galina Yakovlevna Belyakova, Siberian Federal University, 660041, Krasnoyarsk, Svobodnij \\ Prospect, 79, Russian Federation.
}

\author{
Received: November 2, 2014 Accepted: November 11, 2014 Online Published: February 25, 2015 \\ doi:10.5539/ass.v11n6p37 \\ URL: http://dx.doi.org/10.5539/ass.v11n6p37
}

\begin{abstract}
This article discusses issues related to the content of the definitions "innovative susceptibility" and "regional innovation system"; reveals characteristics and classification of innovative susceptibility of the region, systematized its determining factors; the author's approach to the time-processing performance evaluation is suggested; shows the possible fields of application of evaluation subjects of innovative activity. Determining the level of innovation receptivity helps to identify priority areas for improvement processes of innovation governance in the region.
\end{abstract}

Keywords: innovation susceptibility factors, signs, regional innovation system, civil society, governments

\section{Introduction}

External challengers and internal needs of the economy of the modern state as a cause of the priority select innovative scenario. Acting as the main driving force of the scientific and technical progress, innovation at the same time has a progressive effect on the economic processes that are covered in the works of well-known foreign and domestic economists-J Schumpeter (1982), Nelson (1993), Lundvall (1992), B. Kondratiev (1989) and others. However, efficiency of the implementation of innovation, its effectiveness is largely determined by how much participants of economic relations are ready for perception. This allows us to introduce the term "innovation susceptibility."

Despite the fact that in the scientific use, as well as in a number of Russian legislation, the term is used quite often in the existing conceptual framework there is no rendering of innovation perception, which determines the feasibility of the study. For a more complete disclosure of the nature of this definition it's appropriate to give an overview of existing definitions, consider the classification features and groups to determine the levels of formation and the factors influencing them, indicators for the quantitative measurement, as well as the place and role in the regional innovation system.

\section{The Main Part}

Table 1. Characteristics of innovation receptivity

\begin{tabular}{|c|c|}
\hline Name of the feature & Content of feature elements \\
\hline Quality of innovation strategy of the subject & $\begin{array}{l}\text { Appropriate of strategy to mission-purpose and mission-orientation, } \\
\text { environment, potential, targets, other strategies of the subject }\end{array}$ \\
\hline Mobilization level of innovation potential & $\begin{array}{l}\text { Competence of management and subjects of innovative activity in } \\
\text { attracting and using the obvious and latent parts of innovation } \\
\text { potential }\end{array}$ \\
\hline level of attracted investment & $\begin{array}{l}\text { Sufficiency of required on volume and affordable sources of } \\
\text { investment }\end{array}$ \\
\hline Organizational support & $\begin{array}{l}\text { Application of innovation concepts and methods, aimed on a real } \\
\text { competitive advantage }\end{array}$ \\
\hline $\begin{array}{l}\text { Correspondence of nature of the strategic } \\
\text { situation and adequate reactions of the subject }\end{array}$ & $\begin{array}{l}\text { Correspondence of the environment and the level of strategic and } \\
\text { tactic activity innovators }\end{array}$ \\
\hline Validity of innovation susceptibility & $\begin{array}{l}\text { Conditions for the creation and promotion of innovation, working out } \\
\text { strategic innovative changes }\end{array}$ \\
\hline
\end{tabular}


Innovative susceptibility-is historically arisen economic phenomenon relevant to certain level of scientific and technological progress and market relations. Innovative susceptibility is a process of the innovation evaluating, the initiation of its adoption, the implementation of innovation and making it common (conversion of innovation into the usual, which is characterized by the predictability of the behavior of workers and repetitive patterns of activity) (Maslennikov, 2010).

Consideration of innovative susceptibility qualimetrically gives the possibility to determine an object of measurement of the sign properties-a quantitative parameter (index). Sign "Innovation susceptibility," reflecting as a comprehensive indicator of a certain group of private property, has its own characteristics (Table 1).

Susceptibility depends on the objective characteristics of the object of perception from that activity, which includes the processes of perception that justifies opportunity to see it from the perspective of different classification groups. Investigation of susceptibility by classification groups allows to distinguish types of innovation susceptibility, similar by any of features, to determine the form of susceptibility in order to identify the behavior of the subjects of innovation, etc. Classification groups are determined by coverage degree of subjects (scale), significance of certain types of innovation susceptibility to the economy.

In modern scientific economic literature there are a variety of approaches to classification of innovation susceptibility.

Innovative susceptibility should be studied in terms of the level of the system. From the position of systematic approach to scientific work it is possible to point out four main levels of economical subsystems (individual, organization, region, society), the impact level of innovation processes on which is determined by the presence and status of various conditions (factors) of the formation of innovation susceptibility (Egorov, 2006).

The degree of susceptibility of innovation at the individual level is largely determined by how high is the educational level of their creators and consumers, the level of their income, as well as state of the innovative characteristics of the surrounding socio-economic environment, appeared, particularly in the level of information and innovation culture.

Innovative susceptibility of organization is appeared in its ability to appropriate and rational use the available resources and results of innovation in satisfying the needs of the market; timely and effective manner to create organizational and economic mechanisms, aimed to reduce the life cycle of innovation and commercialization; create flexible organizational structures; to form a strategy for competitiveness based neo-introductions; to create a special atmosphere (culture) in the organization to use and develop creative initiative personnel of the enterprise, as well as experience and potential of professionals under intercompany agreements and alliances; lead management, organizational structure and organizational culture of the company in line with the strategy to ensure competitiveness and retention factors competitive advantage (Vasiliev, 2007).

The influence of regional characteristics on the innovation processes is emphasized in "Oslo Manual." It's stressed that "Regional differences in the levels of innovation activity may be substantial, and identification of key characteristics and factors contributing to innovative activity and the development of specific industries at the regional level can help understanding innovative processes and be useful for policy-making" (Oslo Manual, 2006).

The authors propose to consider innovative susceptibility of the region as the existence and capability of regional entities and bodies of the executive power to create, execute and implement innovation process based on existing conditions and resources within a particular and ongoing state and regional innovation policy (Vladimirova, 2011).

Susceptibility of society to innovation in the whole is a complex, multifaceted process that combines and takes into account the particular susceptibility of innovation by individuals, organizations, regions, since all of these sites are in close cooperation. Innovative susceptibility of the society (social sensitivity)-is deeply conscious society and the majority of Russian citizens (and not just by individual scientists, specialists, experts and politicians) need in innovative development. It is determined by characteristics of the social and economic situation, technological and sectoral structure of the economy of the region; the education system.

From our point of view, this classification group can be logically complemented by the international level, as in the context of globalization there is an association of subjects of different industries, regions, states in solving problems of innovative development. All levels of considering innovation susceptibility are combined with each other and interact through a network of direct and indirect connections, so the development of innovative susceptibility of the region seems complex multi-layered process and serves as one of the necessary conditions for the formation and functioning of the regional innovation system. 
By the shape of the innovation perceptual sensitivity are classified into two groups. Indention of active and passive forms of behavior is associated with the subjects of innovative activity. Active susceptibility is inherent to entities producing and disseminating innovations. Passive susceptibility is characterized by strong demand for innovation from the entities acting as consumers.

Selection as classification a group of adaptation subjects' strategies to innovative processes is governed by the interdependence of the results of the micro-level adaptation of subjects and depth and perspective of innovative development. Strategy of recognizing innovative processes by all or most of the subjects of the region suggests active involvement in innovation processes, the use of advantages of innovative products, leading to an acceleration of innovation development in the regional economics. Strategy of recognizing innovation processes by minor part of regional entities (passive susceptibility) is characterized by the alienation of innovation processes and the failure in taking part in them, not fully usage of innovative products. The strategy of refusal innovative changes by vast majority of subjects in the region is expressed in conscious countering to the flow of innovation processes, negative attitude towards innovative transformations.

A number of publications consider innovative susceptibility regarding innovations themselves and information about them, with respect to knowledge and best practices:

1) susceptibility to information about innovations (new books, articles, exhibitions, conferences, new education courses) and a willingness to collect, study and apply obtained information regularly;

2) susceptibility to best practices, creating within the organization and experience of its competitors, the willingness to learn this experience, measure their own and others' achievements and compare them (ready to benchmarking);

3) susceptibility to own innovations, new technologies and new products, susceptibility to the innovation process and innovation and a willingness to overcome difficulties in mastering innovations;

4) as the level of self-actualization of employees and the availability of the needs to intellectual labor, educational and career development, solving situations and challenges, to participate in projects, to success, to results and achievements, the willingness to include innovations in your business process (Barancheev 2005).

Approaches to classification of innovation susceptibility discussed in this article find practical application in the conditions of formation and functioning of regional innovation systems, those are part of the national innovation system. Regional innovation system-is a subsystem of the national innovation system, representing the set of subjects and explain-innovation projects, regulatory, operating within a certain territory, to promote the economic growth of the region on the basis of innovative development.

The main features of regional innovation systems are:

- The nature of study;

- Diversification of the regional industrial complex;

- Target orientation of innovation in the region;

- The existing system of innovation development in the region (Tishkov, 2009).

Regional innovation system is influenced by the most important conditions:

- National (federal) innovation system;

- Regional policy pursued at the federal level and to ensure the efficient use of the regions' potential and the alignment of their economic development;

- Social and economic policy in the region, which is largely determined by the features of the region.

The processes of formation and functioning of regional innovation systems in modern conditions should be considered as a result of territorial development, the direction of which is formed under the influence of globalization and regionalization of the modern economic system as a whole.

Consideration of the content and features of definitions "innovative susceptibility" and "regional innovation system" allows to conclude that the innovative susceptibility acted, as a tool for management of innovative activity, assessing the readiness of all subjects in regional innovation system in the implementation of innovative processes.

The authors propose a methodical approach of innovative assessment of the susceptibility of the region, based on developing comprehensive index. Analysis of the concept "innovation susceptibility" as an object of scientific research has allowed to allocate its following characteristics: 
- there should be a comprehensive indicator of the region as an economic entity;

- as an economic category it should be considered with respect to specific areas: in this case-with respect to the ability to suspect the innovation;

- Multidirectional, i.e. the ability to implement innovations in different sectors-industrial, services, science and others.

Formation evaluation of innovation susceptibility should be carried out on the basis of after-following principles:

- A list of target indicators should come from developed official documents of federal and regional levels on the main directions of development of science and innovation in the future;

- The contents of the target indicators must comply with international practice of the use of similar parameters for the evaluation of innovative development in the advanced countries and take into account the experience of the regions of the Russian Federation in decision such problem;

- A set of proposed indicators should ensure possibility of a comparative analysis of the subjects of the Russian Federation in the appropriate Federal District and Russia in the whole;

- Taking into account the previous principle it is necessary to use a limited number of indicators reflecting the main components of the innovation susceptibility of the region;

- Target indicators should serve as a basis for establishing targets the formation innovation policy in the future.

Being a complex indicator, innovative susceptibility reflects not only the dynamic parameters of the economic development, but also the factors of demographic components, institutional (formal and informal) software and allows to take management decisions. Purpose of assessment of innovation susceptibility by different subjects of innovation activity is shown in Figure 1.

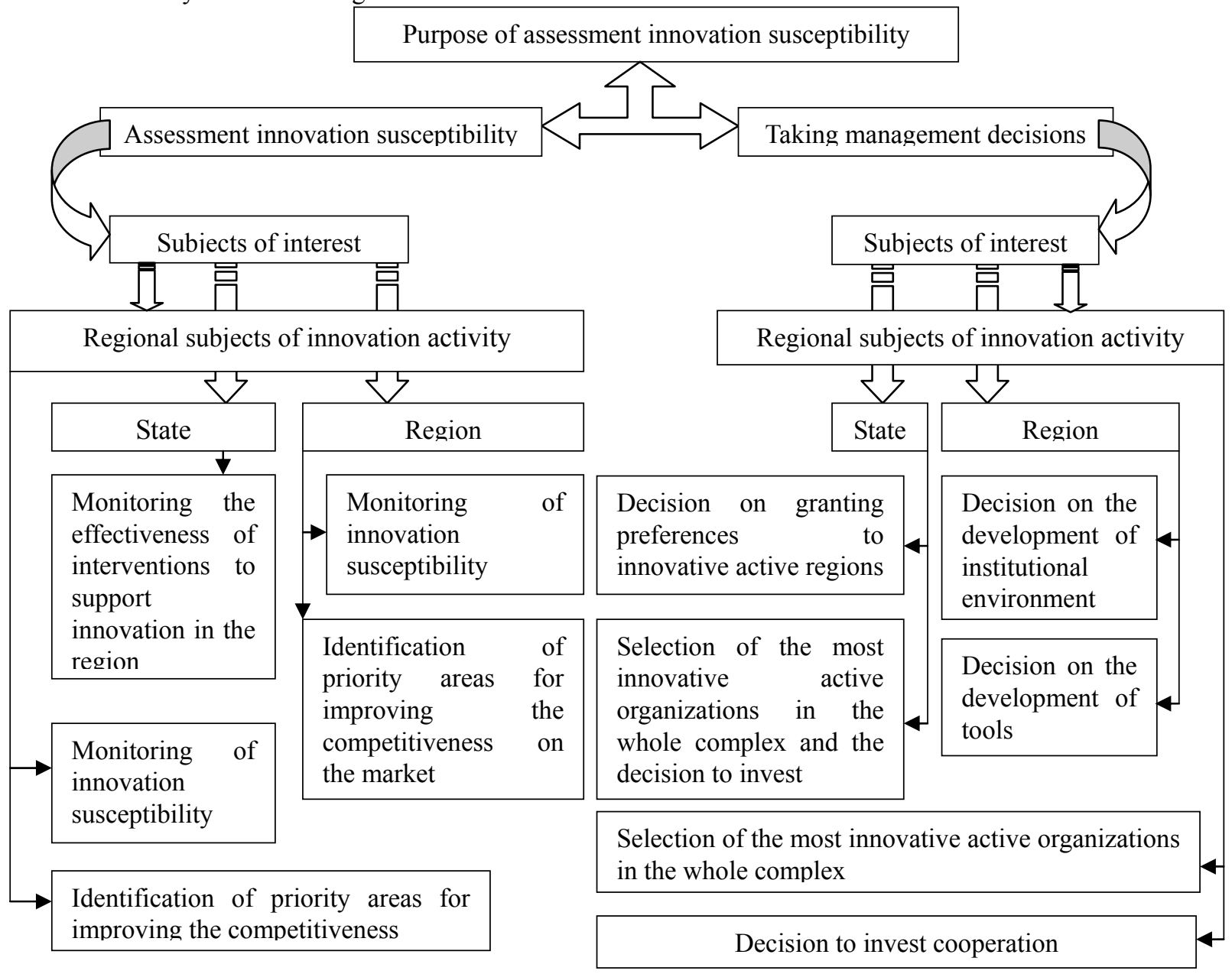

Figure 1. Assessment of innovation susceptibility of the region 
The control system of innovation susceptibility at the regional level is made up of innovative susceptibility of businesses structures, innovation receptivity of state administration, innovation receptivity of businesses and individuals engaged in economic activity and living in the region (Figure 2).

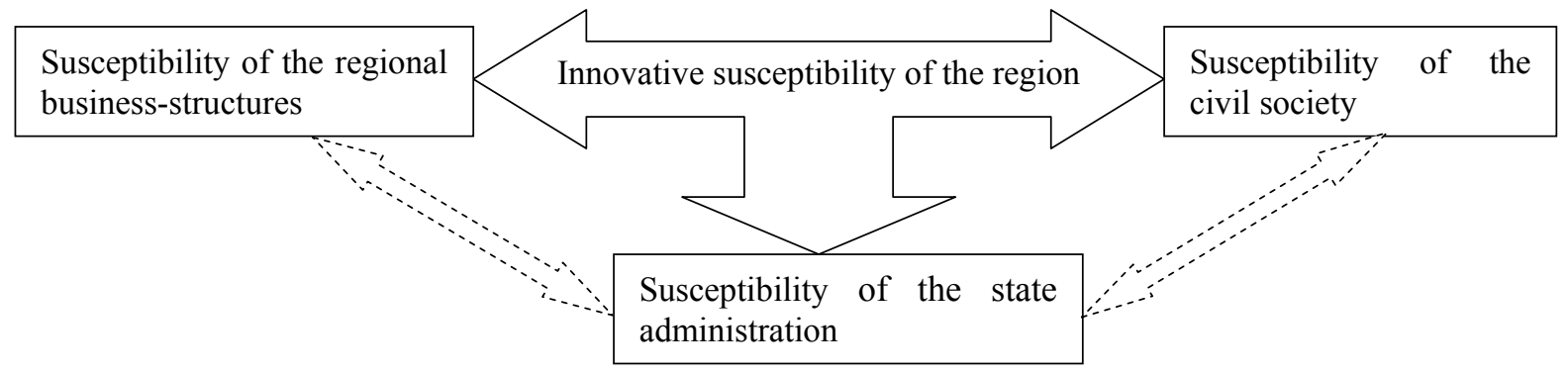

Figure 2. Subjects innovative susceptibility of the region

Innovative susceptibility state administration in modern conditions is a set of methods, tools, structures involved in organizing and promoting the development of innovation and implementation of national and regional innovation policy.

Innovative susceptibility of regional innovation system is influenced by several factors: the innovation activity, the level of technological development, human factors, financial, and credit and investment security, structural and infrastructural support. Table 2 summarizes the main issues affecting the susceptibility of various innovative subjects.

Table 2. Matrix of innovation susceptibility factors

\begin{tabular}{|c|c|c|c|c|c|}
\hline Subjects & $\begin{array}{l}\text { Factors } \\
\text { Innovation } \\
\text { activity of the } \\
\text { subject }\end{array}$ & $\begin{array}{l}\text { lical and } \\
\text { ological } \\
\text { s }\end{array}$ & The huma & $\begin{array}{l}\text { Financial-credit } \\
\text { and investment } \\
\text { support }\end{array}$ & $\begin{array}{l}\text { Structural and } \\
\text { infrastructural support }\end{array}$ \\
\hline Region & $\begin{array}{l}\text { - The conditions } \\
\text { for innovation; } \\
\text { - The presence of } \\
\text { large business } \\
\text { structures; } \\
\text { - The capacity } \\
\text { and experience } \\
\text { of small and } \\
\text { medium-sized } \\
\text { enterprises; } \\
\text { The effective } \\
\text { coordination of } \\
\text { government } \\
\text { action in the field } \\
\text { of innovation }\end{array}$ & $\begin{array}{l}\text {-non-balanced } \\
\text { structure of the } \\
\text { technological } \\
\text { capital; } \\
\text { non-effective } \\
\text { use of } \\
\text { technological } \\
\text { capital }\end{array}$ & $\begin{array}{l}\text {-demographic } \\
\text { situation; } \\
\text { - Unemployment; } \\
\text {-level of income; } \\
\text {-social conditions; } \\
\text {-structural (by } \\
\text { occupation) and an } \\
\text { absolute shortage } \\
\text { of staff; } \\
\text {-personal mobility }\end{array}$ & $\begin{array}{l}\text { Sufficiency of } \\
\text { regional budget; } \\
\text {-availability of } \\
\text { extra budgetary } \\
\text { sources; } \\
\text { - Co-financing } \\
\text { from the federal } \\
\text { budget; } \\
\text {-target financing }\end{array}$ & $\begin{array}{l}\text { - Occurrence of industries } \\
\text { in priority areas; } \\
\text {-institutional structure; } \\
\text { - Occurrence of innovation } \\
\text { infrastructure; } \\
\text {-Regional innovative } \\
\text { legislation; } \\
\text {-regional innovation, } \\
\text { scientific- technological, } \\
\text { industrial policy; } \\
\text { - Methodical and } \\
\text { analytical documents; }\end{array}$ \\
\hline $\begin{array}{l}\text { Business } \\
\text { structures }\end{array}$ & $\begin{array}{l}-\quad \text { Economic } \\
\text { incentive to } \\
\text { innovate; } \\
\text { - The demand for } \\
\text { innovative } \\
\text { products } \\
\text { - A weak } \\
\text { correlation of } \\
\text { depending the } \\
\text { eventual } \\
\text { outcomes from } \\
\text { collaboration to }\end{array}$ & $\begin{array}{l}\text { - Depreciation } \\
\text { of fixed assets; } \\
\text { - The } \\
\text { availability and } \\
\text { accessibility of } \\
\text { modern } \\
\text { domestic } \\
\text { equipment' } \\
\text { - Lack of } \\
\text { interest; } \\
\text { - Centralization }\end{array}$ & $\begin{array}{l}\text { - The availability } \\
\text { necessary } \\
\text { specialists; } \\
\text { - The ability of the } \\
\text { personal to percept } \\
\text { innovation; } \\
\text { - Age; } \\
\text { intra-training; } \\
\text { - High level of } \\
\text { wages; } \\
\text { - The number of }\end{array}$ & $\begin{array}{l}\text { - The availability } \\
\text { of funding; } \\
\text { - The availability } \\
\text { and accessibility of } \\
\text { financial } \\
\text { instruments; } \\
\text { - The cost of } \\
\text { financial } \\
\text { resources; } \\
\text { - The imbalance of } \\
\text { investment }\end{array}$ & $\begin{array}{l}\text { - Presence of internal R \& } \\
\text { D units in the structure of } \\
\text { the enterprise; } \\
\text {-Scientific and technical } \\
\text { cooperation; } \\
\text { - The presence of market } \\
\text { institutions (development } \\
\text { institutions, venture capital } \\
\text { funds, etc.); } \\
\text {-State innovative } \\
\text { legislation; }\end{array}$ \\
\hline
\end{tabular}




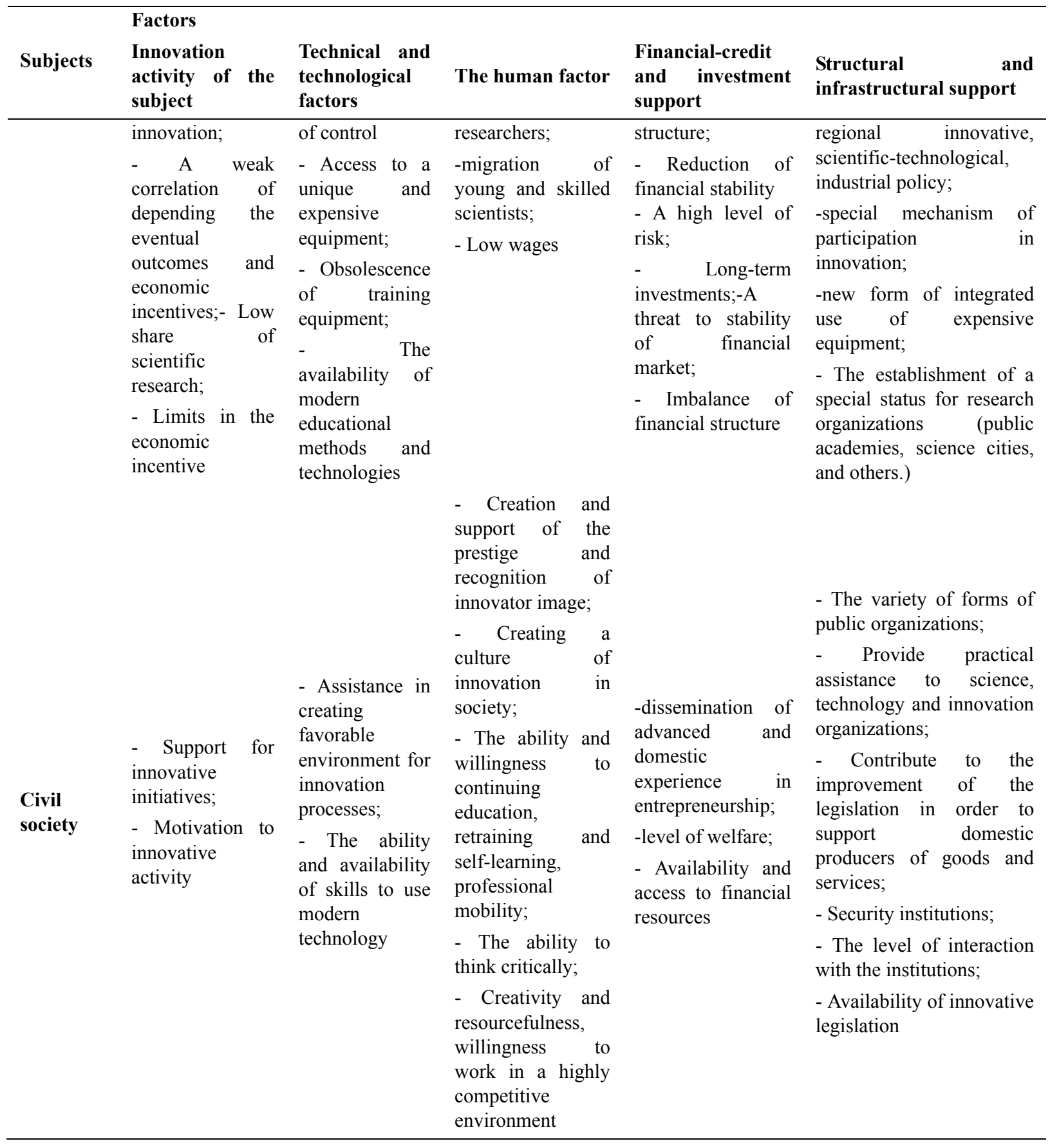

Despite the fact that the innovation vector of development of the Russian economy has been identified over a decade ago, to the present time the majority of the subjects of innovative activity remains at a low level. The main reasons for this are the lack of motivation to innovate, low demand for innovative products.

Influence of technical and technological factors in the Russian economy had a negative impact, which is expressed at the physical deterioration of the equipment, a significant share of foreign equipment, low rates of adoption of new technologies and the utilization of production areas, there is a gap between the different branches, when the industries with low level economic structure coexist with high rates of application information and communication technologies.

In many official documents and a number of publications on innovation management, in recent times the focus is on the human factor. Susceptibility of the population to innovate depends on a number of parameters: quality of life, age structure, level of education, professional component, which, in turn, are terms of quality of life of the population and are used internationally to calculate the Index of human potential (IHP) (Petrova, 2006). These 
figures are deeply interrelated with the level of innovative development, as evidenced by the results of research conducted by the National Research University "Higher School of Economics" (Arkhipova, 2013), which indicate the presence of "mirror symmetry" influence of innovation activity on the well-being of the population. Russia by a combined indicator of well-being refers to the IHP States with a high level of development and moved to 66 place out of 187 countries in 2011 to 55th in 2013 out of 173 countries (Report, 2011, 2013). At the same time, in recent years a clear tendency to reduce the number of employees in research and development is seen. Simultaneously recorded increases in age of scientific personnel at a low proportion of young scientists. Among the acute problems, you should also include a shortage of highly qualified personnel.

A significant factor in innovation susceptibility of all stakeholders is a structural and infrastructural support. The lack of an integrated system of innovative federal law covering all aspects and stages of the innovation is projected on a regional level. Systematization of the impact factors on the level of the subject has identified the specific conditions of formation innovative susceptibility of the region, among which are the effective coordination of government action in the field of innovation, the presence of the innovation infrastructure, innovative regional legal framework of regional innovation policy in the region.

As part of the most important factors that give a true and adequate assessment of the formation and functioning of the regional innovation system methodological support is considered. Integration of the Russian economy in the global determines the need to use the evaluation of innovative processes in the region, international indices, which include the Global Innovation Index, the indicators of the European Innovation Scoreboard 2010, 2011, the American Science Foundation (NCF) (The Global Competitiveness Report, 2012; Crossing the next regional frontier, 2009), the Frascati group (OECD, 2002) and others. In this part, there are a number of methodological problems due to the lack of national statistical database of indicators and survey instruments that meet international standards.

\section{Conclusion}

Thus, the reference to scientific literature suggests that the definition "innovative susceptibility" as a whole is steel poorly understood. If there is a change in the interpretation, classification criteria and group allocation levels of formation we need some standardization of existing research results in legal format. It should also be emphasized that in the context of globalization it becomes particularly relevant to increase innovation susceptibility of the regions, which is a complex system consisting of a set of subjects, objects, innovation activity, resources and factors determining it, which, in turn, form the quality of life of the population. Now, the Russian practice of formation and functioning of regional innovation systems, there are a number of methodological, methodical, and organizational problems requiring a prompt solution.

\section{References}

Arkhipova, M. Y. (2013). Innovation and standard of living: A study of the relationship and the main trends of development. Questions of statistics, 4, 45-53.

Barancheev, V. P. (2005). Measurement of innovation activity of the company as its competitive strength. Management today, 4, 17-21.

Crossing the next regional frontier. (2009). Information and Analytics Linking Regional Competitiveness to Investment in a Knowledge-Based Economy. U.S. Economic Development Administration. Retrieved from $\mathrm{http}: / / w w w . s t a t s a m e r i c a . o r g / i n n o v a t i o n$

European Innovation Scoreboard 2010. (2011). Comparative Analysis of Innovation Performance (p. 72). Brussels.

Freeman, C. (1995). The National System of Innovation in Historical Perspective (Vol. 19, No. 1). Cambridge Journal of Economics.

Human Development Report 2010, 20th anniversary edition. (2010). The Real Wealth of Nations: Pathways to Human Development. Published for the United Nations Development Programme (UNDP), Publishing House the "Whole world".

Kondratiev, N. D. (1989). Problems of economic dynamics (p. 526). M.: Economics.

Lundvall, B. A. (1992). National Systems of Innovation: Towards a Theory of Innovation and Interactive Learning. L.: Pinter Publishers.

Malmlund, J., Bjornemark, U., \& Landh, S. (p. 28). Innovation: An Imperative for Growth. Deloitte Consulting.

Maslennikov, N. P. (2010). In O. N. N. Melnikova (Ed.), Innovative susceptibility as a basis for the growth of 
innovative activity of the organization (pp. 82-88). Collection of reports on the results of international scientific-practical conference, Moscow, March 29-April 9, 2010. M.: Creative Economy. Retrieved from http://www.creativeconomy.ru/articles/21842

Nelson, R. (1993). National Innovation Systems. A Comparative Analysis. Oxford: Oxford University Press.

Oslo Manual. (2006). Recommendations for the collection and analysis of data on innovation (3rd ed., p. 191). Align-valued publication of OECD and Eurostat. Organization for Economic Cooperation and Development-parameter statistical Office of the European Communities. Moscow.

Petrova, A. T. (2006). In A. T. Petrova (Ed.), Theory, methodology of statistical research and practice of quality management for the population of the region (p. 303). Monograph. Publisher Finance and credit Moscow.

Proposed Standard Practice for Surveys of Research and Experimental Development-Frascati Manual (6th ed.) (OECD). (2002).

Schumpeter, I. (1982). Theory of economic development (p. 277). M.: Economics.

The Global Competitiveness Report 2010-2011. World Economic Forum. Retrieved from http//www.gcr. weforum.org

Tishkov, S. V. (2009). Theoretical bases of formation of regional innovation system (p. 168). Innovation development: Materials of the I Youth economic forum, November 13-14, 2008, Petrozavodsk. Petrozavodsk: Karelian Research Centre, Russian Academy of Sciences.

Vasiliev, V. L., Shigapov, Z. G., Bakaev, A. V., Habibullin, I. F., \& Gaifullin, R. N. (2007). Organizational and economic mechanisms for financing innovation of high school. Innovations, 5, 51-56.

Vladimirova, O. N. (2011). Innovative susceptibility of the region: Conditions of formation and management: Monograph. In O. N. Vladimirova (Ed.), Krasnoyarsk state institute of economics and trade (p. 146).

Yegorova, M. V. (2006). Modeling innovation susceptibility of region's economy (p. 220). Kazan: Kazan. University.

\section{Copyrights}

Copyright for this article is retained by the author(s), with first publication rights granted to the journal.

This is an open-access article distributed under the terms and conditions of the Creative Commons Attribution license (http://creativecommons.org/licenses/by/3.0/). 